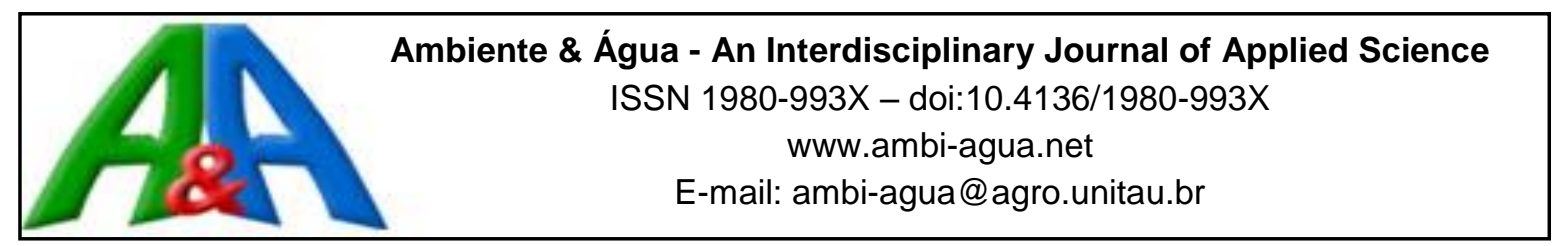

\title{
Sustainability of a scientific journal
}

\author{
doi:10.4136/ambi-agua.1422
}

\section{Getulio Teixeira Batista}

\author{
Universidade de Taubaté (UNITAU), Taubaté, SP, Brazil \\ Graduate Program in Environmental Sciences \\ Editor-in-Chief of Ambi-Agua Journal \\ e-mail: ambi-agua@agro.unitau.br
}

\begin{abstract}
In this editorial, we discuss the necessary steps to guarantee the sustainability of Ambiente \& Água journal as it grew in recognition by the scientific community. To publish world class scientific papers of professional quality, considerable amount of resources are necessary. Therefore, we will follow the trend of successful journals that have raised several funding sources to support the processing costs to publish in cutting edge technology that requires interoperability throughout a variety of platforms. We reviewed several procedures used by those journals and made the decision to adopt the "author pay" policy to help to sustain the operation of Ambiente \& Água journal. In this $25^{\text {th }}$ issue, we are publishing 15 peer-reviewed papers in a variety of environmental themes.
\end{abstract}

Keywords: Ambiagua, environment, water resources, peer review.

\section{Sustentabilidade de um periódico científico}

\section{RESUMO}

Neste editorial, discutiram-se medidas necessárias para garantir a sustentabilidade da revista Ambiente \& Água à medida que ela cresce em reconhecimento pela comunidade científica. São necessários recursos elevados para se publicar artigos científicos de nível internacional e de qualidade profissional. Portanto, foi analisada a tendência das revistas de sucesso que têm levantado diversas fontes de financiamento para apoiar os custos editoriais para publicar com tecnologia de ponta, que permite a interoperabilidade em diversas plataformas. Os diversos procedimentos usados por esses periódicos foram analisados e tomou-se a decisão de adotar a política de "autor paga" para sustentar a operação da revista Ambiente \& Água. Nesta $25^{\mathrm{a}}$ edição, são publicados 15 artigos revisados por pares que abrangem uma variedade de temas ambientais.

Palavras-chave: Ambiagua, ciências ambientais, recursos hídricos, revisão por pares.

\section{DISCUSSION}

This editorial discusses the actions of Revista Ambiente \& Água - An Interdisciplinary Journal of Applied Science to cope with the growing editorial demand resulted from the increasing number of submissions. Off course, a scientific journal has to publish high quality papers that promote the advancement of science following ethical principles and sound peer review process. It is essential that all issues be published rigorously on time. To accomplish 
this with professionalism, it is necessary to have a funding framework that guarantees the quality standard for a world class journal.

We examined several models used by consolidated and in ascension journals. Usually, costs can be covered by article processing fees, publication fee, advertisement, sponsorship, grants from foundations and from government agencies, donations, and institutional contributions from the journal host, including office space, personnel, communication expenses, software licenses and web hostage (Crow, 2009). We should add the payment for journal subscription or paper access of non-open access journals. All these possible sources of funding have their limitations and implementation difficulties. Thus, Mueller (2009) suggested that the most adopted practice is to charge a publication fee, i.e. the authors pay, in combination with other sources.

Journals' signature, a traditional source of fund, became unsustainable even for an institution such as Harvard University with an annual budget of US\$ 6 billion (Righetti, 2012). The trend is to use Open Access journals. This same source indicates that to publish an approved paper costs US\$1,500 per article, in average. The benefit of it is that the article is freely accessible afterwards.

In fact, cost varies a lot among journals depending on their impact in the scientific community and prestige. Cost of first-copy of a paper or paper-plus-electronic production per article is in the range of US\$ 4,000-5,000 (Odlyzko, 1997). He speculated 17 years ago that for electronic journals costs per article could be as low as US\$ 250-1,000 for electronic journals, which is the current median for scholarly publication and the trend to lower costs and increased visibility.

In Brazil, CAPES, the Coordination for the Improvement of Higher Education Personnel, pays for the access of electronic scientific journals of commercial publishers. In 2011, CAPES spent R \$ 133 million for the access to 31 thousand scientific journals by 326 federal and state institutions in Brazil (Righetti, 2012). According to Packer (2011), most Brazilian journals are funded by the government mostly by including the infrastructure and personnel of the responsible publisher. The traditional funding source is the National Program for Scientific Journals Edition and Publication of CNPq and CAPES. In 2014, Ambiente \& Água journal received a grant from this program. Although it has been an important support, it is short to cope with the demand of new services, such as increasing the number of articles in English and the production of high quality $\mathrm{xml}$ archives.

Taking the SciELO collection as an example, just to publish and keep the journals online it has been spent $\mathrm{R} \$ 40$ to $\mathrm{R} \$ 50$ thousand Brazilian Reais per journal by public funds, per year (Packer, 2011). This corresponds to $\mathrm{R} \$ 600.00$ per article. On top of this cost, one should add the institutional investments on the journals. In June 10, 2012, Abel Packer in an interview to Romulo Orlandini (Packer, 2012) concluded that the processing cost of a quality journal that has peer review, text edition and revision of the English Language, made by native speaking reviewers, $\mathrm{xml}$ formatting, and online publishing varies from $\mathrm{R} \$ 500.00$ to $\mathrm{R} \$$ 3,000.00 per published article. This cost is a function of the thematic area, text idiom, complexity of the articles in terms of figures, tables, etc. and the number of published articles and rejection rate, among other factors.

Inspired by a reflection presented at the 2013 ABEC meeting by Príncipe and Barradas (2013) that investigated 122 Brazilian journals and concluded that 41 journals charge the authors to cover publishing expenses, we examined the submission instructions of some Brazilian journals to see how they deal with authors' charges. For instance, the Journal of Venomous Animals and Toxins including Tropical Diseases, is charging £1170/\$1960/€1410 for article processing since 2013 (http://www.jvat.org/about\#apc). 
Ambiente \& Sociedade journal is charging $\mathrm{R} \$ 85.00$ for article submission (http://submission.scielo.br/index.php/asoc/about/submissions\#onlineSubmissions). This value is not refunded if the article is rejected.

Scientia Agricola journal (http://www.scielo.br/revistas/sa/iinstruc.htm) charges authors if neither the first author nor the corresponding author subscribe to Scientia Agricola, the following fees: US\$ 60.00 per printed page, up to $6^{\text {th }}$ page; US\$ 150.00 per each additional page; US\$ 80.00 per color page.

Revista Brasileira de Engenharia Agrícola e Ambiental - Agriambi (http://www.agriambi.com.br/) since January $1^{\text {st }}$, 2014 is charging R $\$ 130.00$ per submission and $\mathrm{R} \$ 20.00$ per page of the last version of the text for publication.

Ciência e Agrotecnologia (http://www.scielo.br/revistas/cagro/pinstruc.htm) has a publication charge of $\mathrm{R} \$ 30.00$ per page up to six pages of the article after edition and $\mathrm{R} \$ 60.00$ per additional page. They have also a submission charge of $\mathrm{R} \$ 80.00$, not refundable, but that may be credited in the final cost of the article.

Revista Brasileira de Recursos Hídricos RBRH (http://www.abrh.org.br/SGCv3/index.php ?PUB=1\&PI=InsSubArt) will charge beginning July 15, 2014, R $\$ 60.00$ for members of ABRH and $\mathrm{R} \$ 250.00$ of non-members for submissions. The submission fee will not be refunded if the manuscript is rejected for publication. All values mentioned were consulted in the journal's sites on June 13, 2014.

\section{CONCLUSION}

Considering the increased cost for publication of Ambiente \& Água journal, due to the current number of submissions, new demands from the SciELO collection including the production of articles in xml and pdf formats, increasing the number of articles in English, and the insertion of the journal in several collections, in social and science networks, and the overall professionalization of the journal, we will begin to charge authors for publishing beginning July $15^{\text {th }}, 2014$. Fees will be published in the journal site in due time.

\section{REFERENCES}

CROW, R. Income models for open access: an overview of current practice. Scholarly Publishing \& Academic Resources Coalition, Dupont Circle. 2009. 56p. Available in: <http://www.academia.edu/download/30306140/incomemodels_v1.pdf>. Access in: June 2014.

MUELLER, S. P. M. Quem financia nossos periódicos? Um estudo na base SciELO sobre a relação entre áreas de conhecimento, editoras e financiamento. In: ENCONTRO NACIONAL DE PESQUISA EM CIÊNCIA DA INFORMAÇÃO, 10., 2009, João Pessoa. Anais... João Pessoa: IBICT, 2009. 1 CD-ROM.

ODLYZKO, A. The economics of electronic journals. First Monday, v. 2, n. 8, p. Aug. 1997. http://dx.doi.org/10.5210/fm.v2i8.542

PACKER, A. L. Os periódicos brasileiros e a comunicação da pesquisa nacional. Revista USP, São Paulo, n. 89, p. 26-61, março/maio 2011. 
PACKER, A. L. Entrevista: Abel Packer, um dos idealizadores da SciELO (Scientific Electronic Library Online) fala sobre desafios desta rede, custo de manutenção, publicações em português e faz projeções sobre o futuro das bibliotecas virtuais. ComCiência, an Electronic Magazine of Scientific Journalism, ed. 79, 10 jun. 2012. Interviewer: R. Orlandini. Available in: <http://www.comciencia.br/comciencia/? section $=8 \&$ tipo $=$ entrevista\&edicao $=79 \&$ print $=$ true $>$. Access in: June 2014.

PRÍNCIPE, E.; BARRADAS, M. M. Modelos de negócios de revistas científicas brasileiras: author Pay? In: ENCONTRO NACIONAL DE EDITORES CIENTÍFICOS, 14., 2013, São Pedro. Anais... Available in: ocs2.abecbrasil.org.br/index.php/ENEC/ENECUSP/ paper/viewFile/47/52. Accessed in: June 2014.

RIGHETTI, S. Universidade Harvard reclama do preço de revistas científicas. Folha de São Paulo, São Paulo, 01 maio 2012. Available in: http://www1.folha.uol.com.br/ciencia/ 1083979-universidade-harvard-reclama-do-preco-de-revistas-cientificas.shtml. Access in: June 2014. 